\title{
Physico - Chemical and Morphologic Structural Characterization of the Red Mud Obtained in the Romanian Alumina Plant
}

\author{
VASILE GEORGESCU1*, MIHAELA BOMBOS², CATALINA CALIN, DORIN BOMBOS³ \\ ${ }^{1}$ Romanian Academy,Institute of Physical Chemistry Ilie Murgulescu, 202 Splaiul Independentei, 060021 Bucharest, Romania \\ ${ }^{2}$ National Institute for Research Development for Chemistry and Petrochemistry- ICECHIM-Bucuresti, 202 Spl. Independetei, \\ 060021, Bucharest, Romania \\ ${ }^{3}$ Petroleum-Gas University of Ploiesti, 39 Bucuresti Blvd, 100680, Ploiesti, Romania
}

\begin{abstract}
The red mud is the main insoluble waste product from the manufacture of alumina by the Bayer hydrometallurgical process. Due to the accumulation in large quantities (0.8-1.2 metric tons waste / 1 metric ton of alumina) with a relatively high content of residual alkali and small granulation, it has been subject to many research activities, especially related to the techniques of neutralizing and enhancing its reuse under the form of various subproducts. This paper presents the results of the work undertaken by the collective of authors to evaluate the physico-chemical and morphological structure of red mud resulting from alumina production. The physico-chemical and morphological structure were analyzed using complex analytical methods (ICP-AES/OES, DCP, AAS, EDS-EDAX, SEM, DTAC, XRF, XRD, optical microscopy). The aim was to identify potentially active compounds for various environmental applications. To estimate the average chemical composition, by element, we used dispersion analysis, through the Gauss normal distribution method.
\end{abstract}

Keywords: red mud, materials characterization, alumina, waste product

Mainly, alumina (aluminium trioxide) is obtained by the hydrometallurgical Bayer process, through the chemical treatment of bauxite ore (most often of lateritic and / or karstic origin) with concentrated caustic soda solutions $[1,2]$. Manufacturing one metric ton of alumina requires 23 metric tons of bauxite and generates up to about 1.2 metric tons of solid waste in the form of red mud, accumulating annually worldwide million tons of waste. Bauxite ore is a mixture of hydrated aluminium oxides containing silica, iron oxides and other impurities. Processing conditions vary from one type of bauxite to another, mainly by applying different temperature and pressure levels in the process of solubilisation in alkaline medium.

The insoluble red mud waste resulting in the manufacture of alumina by the Bayer process, requires special attention, due to at least two of its main characteristics: high levels of alkali content as a result of the residual content of caustic soda, indicated by a high $\mathrm{pH}$ range in the field of 8-13; and the fine size of solid particles (of the order of microns up to 100 microns). The physical, chemical and mineralogical properties of red mud are determined primarily by the type of bauxite used as raw material, by the action of auxiliary components introduced in different phases of the alumina production process and by the processing conditions of bauxite in the hydrometallurgical Bayer process [3-8].

Compositionally, red mud is a complex material, including many compounds, some similar to those in the composition of the bauxite used as raw material, others resulted from the transformations taking place in various stages of the production process of alumina, as majority components like iron (goethite or hematite), aluminium (Gibbsite and Boehmite, resulted through an incomplete solubilisation of bauxite), alkalis and silica (as various desiliciation products, sodalite, cancrinite, resulted through the solubilisation and recrystalisation of silicoaluminates in bauxite), but also a series of minority compounds (caolinite, anatase, rutile, calcite, hidrogarnet), and also various rare earth elements or other elements found as traces ( $\mathrm{Ba}, \mathrm{Cr}, \mathrm{Ga}, \mathrm{Sn}, \mathrm{V}, \mathrm{Zr}, \mathrm{Y}, \mathrm{Ce}, \mathrm{Gd}, \mathrm{Sr}, \mathrm{U}$, Th, etc.) $[9,10]$.

Red mud is not recycled or used in industrial quantities, with small exceptions [11-30], and with a low economic efficiency, most of the efforts being focused on its neutralization [31]. The analysis of physico-chemical and mineralogical properties of red mud is a key step, very important to identify recycling solutions in the form of potentially active compounds for various environment applications or for the possible recovery of useful elements.

In Romania, a major aluminium producer in Central and Eastern Europe, important amounts of bauxite ore of varying origin were processed over the course of time, mainly in the form of imports, lateritic and karstic type bauxite (gibbsite, gibbsite - boehmite, boehmite and diaspore bauxites), the economic and market factors having usually an important role. Red mud waste resulting from the manufacture of alumina in conditions specific to the Romanian technologies, has been stored over time in the form of dumps, with storage on the ground in closed spaces.

This paper presents results of the research conducted by the collective of authors regarding the evaluation of the physical-chemical and morphological structure of the red mud resulting from alumina production in conditions specific to Romanian technologies, in order to find the main potentially active compounds for various environmental applications.

The physico-chemical and morphological structure were analyzed using complex analytical methods (ICP-AES/OES, DCP, AAS, EDS-EDAX, SEM, DTAC, XRF, XRD, optical microscopy). To estimate the average chemical composition, by element, we used dispersion analysis, through the Gauss normal distribution method. 


\section{Experimental part \\ Sampling}

Red mud samples were taken inside the dumps along the accessible area. Where access was possible, multiple sub-samples were taken which were merged to form a single sample for that location. Red mud samples were collected as informative samples from predetermined locations using similar techniques. Overall, about $80 \mathrm{~kg}$ of red mud residue was collected and stored (stored) in plastic bags until the next day. In the laboratory, the samples of red mud were mixed thoroughly using a stainless steel spatula and transferred in polyethylene closed containers.

\section{Analysis of majority elements and trace elements}

For the analysis of majority elements and trace elements from the red mud, we used qualitative chemical analysis through atomic spectroscopy: atomic absorption spectroscopy (AAS/FAAS), atomic emission spectroscopy (ICP-AES/OES). A significant number of probes were analyzed in parallel. Dispersion analysis was used for assessing the estimated/average content of components, through the Gauss normal distribution method. For this purpose, the following values were calculated: the arithmetic mean $\left(\mathrm{x}_{\text {med }}\right)$, dispersion $(\mathrm{s})$, standard error of the arithmetic mean. The analysis allows the determination of confidence intervals for the real values for chemical elements, for a given threshold of significance $q$ (eq. 1):

$$
X_{\text {med }} \pm \mathrm{tq} \cdot \mathrm{s} / \mathrm{n}^{1 / 2}
$$

\section{Morphological and structural analysis}

For the morphological and structural characterization of the red mud samples, imaging and quantitative compositional determinations were made, corresponding to the

X-ray emission spectrum through EDS-EDAX, SEM, XRF analysis, to investigate the distribution of surface properties on the initial mud samples and samples washed with distilled water and by XRD analysis and optical microscopy in polarized light to determine the mineralogical phase composition. Red mud samples collected from different areas of the landfills were processed and analyzed.

Two of the red mud samples were washed with distilled water in ratio (weight) mud: water of about 1:20, in stages of three washings/sample. The variation of the $\mathrm{pH}$ for the eluates and the necessary amount of water for reducing the $\mathrm{pH}$ of the samples to $\mathrm{pH}=8-8.5$ (about $900 \mathrm{~mL}$ ) were recorded. We observed that the filtrates present fine deposits over time. Initial mud samples and the washed samples were dried to constant weight in oven at about $100-105^{\circ} \mathrm{C}$. The initial mud samples and the washed and dried ones were investigated in terms of image and composition through scanning electronic microscopy and EDS-EDAX (X-ray emission spectrum).

To make imaging determinations a Philips XL 30 ESEM TMP scanning electronic microscope was used, with a resolution of $3.5 \mathrm{~nm}$ at an accelerating voltage for the electron beam of $30 \mathrm{kV}$. Due to the fact that the probes are not conductive, in order to avoid the appearance of the surface electric charge phenomena, a water vapour environment was introduced in the microscope room with an average pressure of 0.7 Torr. Compo type images (differences in gray shades are also differences in the composition of the analysed surface) were obtained from 100, 500, 2000 and 5000x zoom levels, with a backscatter electron detector (BSE). The analysis for determining the chemical composition of samples was performed using an EDS-EDAX spectrometer with energy dispersion with a resolution of $128 \mathrm{eV}$. The data acquisition time was set to a minimum of $35 \mathrm{sec}$, and the results were expressed in weight percents and atomic percents.

To determine the structural phase composition of the red mud, X-ray diffraction analysis (DRX) was used, and the data acquisition was performed on the BRUKER D8 ADVANCE diffractometer with the DIFFRAC ${ }^{\text {PLUS }}$ XRD COMMENDER (BRUKER AXS) software, through Bragg Brentano diffraction, $\theta-\theta$ coupling, in vertical configuration, with $\mathrm{Cu} \mathrm{K} \alpha$ radiation; the materials were scanned in the $2 \Theta$ domain Region $4 \div 74^{\circ}, 2 \Theta$ Step $0.02^{\circ}$; time (s)/step 4.5; scan mode: continous; scan type: Locked Coupled; rotation speed (rot $/ \mathrm{min})$ 120, electronic removal of the CUK $\beta$ component, with the SOL $X$ detector. The phase analysis was performed using the EVA12 software - with the Search / Match Module and the ICDD PDF-2 Release 2006 database.

The red mud study by optical microscopy was conducted using a polarized light microscope, type Axiol Mager Alm, with image capture done by a Canon Power Shot A 640 digital camera, 10X digital zoom, and Axiovision Release 4.6.3 image processing software, on samples prepared through EpoThin resin embedding, according to the MICRO-A2-029 procedure.

\section{Thermal analysis}

The thermal analysis of red mud was performed with a SETSYS EVOLUTION device manufactured by the company SETARAM-FRANCE. The material was subjected to a controlled temperature program, a heating being carried out up to $1100^{\circ} \mathrm{C}$ at a heating rate of $10^{\circ} \mathrm{C} / \mathrm{min}$ and a cooling to $500 \mathrm{at} 10^{\circ} \mathrm{C} / \mathrm{min}$. The attached curves highlight a series of thermal effects related to mass variation. On the TG curve, several mass losses can be observed, due to changes also highlighted on the HEAT FLOW curve by endothermic effects.

\section{Results and discussions}

The physico-chemical analysis of the red mud, performed through complex ICP-AES/OES, DCP, AAS/FAAS techniques, has shown that, as expected, this has a complex composition (table 1 and table 2 ).

Mineralogical and structural analysis of the red mud made by X-ray diffraction (XRD) and optical microscopy also highlighted its complex composition. Mostly it is composed of iron oxides with earth aspect, probably hydrated, figure $1(a, b)$, and contains between 18.97$20.01 \%$ iron, dispersed mainly in hematite $\mathrm{Fe}_{2} \mathrm{O}_{3}(30.4 \%)$ and goethite $\mathrm{FeO}(\mathrm{OH})(9.7 \%)$, and in small quantities in insoluble compounds - muscovite or in compounds generated through lying, hidrogarnet; it also contains between 7.1-7.7\%aluminium, dispersed in mainly diaspore AlO $(\mathrm{OH}) 7.6 \%$, boehmite $\mathrm{AlO}(\mathrm{OH}) 2.3 \%$, gibbsite $\mathrm{Al}(\mathrm{OH})_{3}$ $10.6 \%$, but also in desiliciation compounds, in cancrinite $\mathrm{Na}_{722}\left(\mathrm{CO}_{3}\right)_{932} \mathrm{Al}_{5} \mathrm{Si}_{6} \mathrm{O}_{24} 7.8 \%$ and cancrisilite $\mathrm{Na}_{7.86}$ $\left(\mathrm{Al}_{6} \mathrm{SI}_{6} \mathrm{O}_{24}\right.$ ) $\left(\mathrm{CO}_{3}^{3}\right)^{32}\left(\mathrm{H}_{2}^{6} \mathrm{O}\right)_{3.3}^{6} 11.4 \%$ (zeolitic compounds), or in compounds generated in bauxite solubilisation, hidrogarnet $\mathrm{Ca}_{3} \mathrm{AlFe}\left(\mathrm{SiO}_{4}\right)(\mathrm{OH})_{8} 4.8 \%$, as well as in insoluble compounds, muscovite (K,Na) $(\mathrm{Al}, \mathrm{Mg}, \mathrm{Fe}),\left(\mathrm{Si}_{3.1} \mathrm{Al}\right)$ $\mathrm{O}_{10}(\mathrm{OH}), 1.9 \%$, amesite $\left(\mathrm{Mg}_{2} \mathrm{Al}\right)\left(\mathrm{AlSiO}_{5}\right)(\mathrm{OH}){ }_{3 .} 2.1 \%$, compounds that in addition to aluminium also include the following elements: $2.26-2.36 \% \mathrm{Si} ; 2.68-2.91 \% \mathrm{Na}$; 0.04 $0.077 \% \mathrm{~K} ; 0.232-0.248 \% \mathrm{Mg} ; 3.348-3.697 \% \mathrm{Ca}$, (fig. 2 and table 3). A high humidity level of the red mud was found, between $31.38-32.73 \%$ and calcinations losses $\left(1000^{\circ} \mathrm{C}\right)$ between $39.5-40.47 \%$.

In the magnetic separation, optical microscopy found metallic iron and muschetovite, pseudomorph phase of magnetite $\mathrm{Fe}_{3} \mathrm{O}_{4}$, after hematite $\mathrm{Fe}_{2} \mathrm{O}_{3}$ (fig, $3: \mathrm{a}, \mathrm{b}$ ). The muschetovitisation-martitisation processes are connected 
Table 1

CHEMICAL COMPOSION ON ELEMENTAL OF RED MUD ( wt\%)

\begin{tabular}{|c|c|c|c|c|c|c|c|c|}
\hline \multirow{3}{*}{ Element } & \multicolumn{8}{|c|}{ Esantion } \\
\hline & IA & IB & IC & ID & IE & IF & IG & II \\
\hline & $\begin{array}{c}\text { Element } \\
(\%)\end{array}$ & $\begin{array}{c}\text { Element } \\
(\%)\end{array}$ & $\begin{array}{c}\text { Element } \\
(\%)\end{array}$ & $\begin{array}{c}\text { Element } \\
(\%)\end{array}$ & $\begin{array}{c}\text { Element } \\
(\%)\end{array}$ & $\begin{array}{c}\text { Element } \\
(\%)\end{array}$ & $\begin{array}{c}\text { Element } \\
(\%)\end{array}$ & $\begin{array}{l}\text { Element } \\
\text { (\%) }\end{array}$ \\
\hline $\mathrm{Fe}$ & 1.941 & 17.86 & 17.47 & 17.67 & 21.01 & 19.31 & 23.71 & 19.46 \\
\hline $\mathrm{Al}$ & 7.32 & 7.03 & 6.49 & 7.33 & 8.15 & 7.68 & 7.7 & 7.1 \\
\hline $\mathrm{Si}$ & 2.25 & 2.32 & 2.62 & 2.31 & 2.24 & 2.17 & 2.02 & 2.58 \\
\hline $\mathrm{Ti}$ & 2.73 & 2.23 & 2.16 & 2.75 & 2.46 & 3.11 & 2.34 & 2.23 \\
\hline $\mathrm{Na}$ & 3.31 & 2.92 & 2.57 & 2.4 & 2.65 & 2.03 & 3.22 & 3.24 \\
\hline $\mathrm{Ca}$ & 2.86 & 4.24 & 3.82 & 4.45 & 2.8 & 2.64 & 3.97 & 3.4 \\
\hline $\mathrm{Ba}$ & 0.68 & 0.56 & 0.024 & 0.032 & 0.052 & 0.61 & 0.89 & 0.71 \\
\hline $\mathrm{Mg}$ & 0.26 & 0.24 & 0.3 & 0.2 & 0.24 & 0.2 & 0.24 & 0.24 \\
\hline $\mathrm{V}$ & 0.043 & 0.038 & 0.035 & 0.038 & 0.041 & 0.041 & 0.038 & 0.039 \\
\hline $\mathrm{Zr}$ & 0.058 & 0.023 & 0.009 & 0.035 & 0.03 & 0.051 & 0.038 & 0.032 \\
\hline $\mathrm{Cu}$ & 0.032 & 0.038 & 0.028 & 0.021 & 0.051 & 0.031 & 0.023 & 0.015 \\
\hline $\mathrm{Pb}$ & 0.041 & 0.044 & 0.083 & 0.035 & 0.0720 & 0.056 & 0.048 & 0.053 \\
\hline K & 0.026 & 0.024 & 0.020 & 0.078 & 0.024 & 0.033 & 0.0230 & 0.025 \\
\hline $\mathrm{Zn}$ & 0.015 & 0.012 & 0.012 & 0.011 & 0.019 & 0.016 & 0.02 & 0.018 \\
\hline $\mathrm{Ce}$ & 0.012 & 0.017 & 0.018 & 0.016 & 0.014 & 0.016 & 0.012 & 0.017 \\
\hline La & 0.005 & 0.0061 & 0.0068 & 0.0053 & 0.0052 & 0.0049 & 0.0051 & 0.0057 \\
\hline Sc & 0.0033 & 0.0038 & 0.0039 & 0.0039 & 0.0038 & 0.0025 & 0.003 & 0.0049 \\
\hline $\mathrm{Ga}$ & 0.0028 & 0.0015 & 0.0016 & 0.002 & 0.003 & 0.0031 & 0.0028 & 0.0027 \\
\hline $\bar{Y}$ & 0.0026 & 0.0033 & 0.0033 & 0.0033 & 0.0033 & 0.0025 & 0.0029 & 0.0028 \\
\hline$A s_{\max }$ & 0.002 & 0.002 & 0.002 & 0.002 & 0.002 & 0.002 & 0.002 & 0.002 \\
\hline $\mathrm{Se}_{\max }$ & 0.002 & 0.002 & 0.002 & 0.002 & 0.002 & 0.002 & 0.002 & 0.002 \\
\hline$T h_{\max }$ & 0.002 & 0.002 & 0.002 & 0.002 & 0.002 & 0.002 & 0.002 & 0.002 \\
\hline$U_{\max }$ & 0.002 & 0.002 & 0.002 & 0.002 & 0.002 & 0.002 & 0.002 & 0.002 \\
\hline $\mathrm{Hg}_{\max }$ & 0.001 & 0.001 & 0.001 & 0.001 & 0.001 & 0.001 & 0.001 & 0.001 \\
\hline $\mathrm{C}$ & 0.75 & 0.9 & 0.91 & 0.81 & 0.86 & 0.85 & 1.01 & 0.75 \\
\hline $\mathrm{H}_{2} \mathrm{O}$ & 32.61 & 32.62 & 33.55 & 33.39 & 30.39 & 31.85 & 26.46 & 35.56 \\
\hline $\mathrm{PC}\left(1000^{\circ} \mathrm{C}\right)$ & 42.12 & 40.02 & 42.93 & 40.23 & 38.66 & 37.34 & 37.34 & 41.24 \\
\hline
\end{tabular}

Table 2

ESTIMATION OF AVERAGE CHEMICAL COMPOSITION ON ELEMENTS

(IN \% WEIGHT; STATISTICAL ANALYSIS $\alpha=0.05$ )

\begin{tabular}{|c|c|c|c|c|c|c|c|c|}
\hline \multirow{3}{*}{ Element } & \multicolumn{8}{|c|}{ Statistical analysis } \\
\hline & \multicolumn{8}{|c|}{ Calculation of confidence interval } \\
\hline & $\mathrm{C}_{\text {med }}$ & $S\left(c-c_{m e d}\right)^{2}$ & $\mathrm{~S}^{2}$ & $\mathrm{~S}$ & $S C_{\text {med }}$ & $2 \mathrm{SC}_{\mathrm{med}}$ & $\max$ & $\min$ \\
\hline $\mathrm{Fe}$ & 19.49 & 30.21 & 0.54 & 0.73 & 0.26 & 0.52 & 20.01 & 18.97 \\
\hline Al & 7.35 & 1.78 & 0.03 & 0.18 & 0.06 & 0.13 & 7.48 & 7.22 \\
\hline $\mathrm{Si}$ & 2.31 & 0.28 & 0.01 & 0.07 & 0.03 & 0.05 & 2.36 & 2.26 \\
\hline $\mathrm{Ti}$ & 2.50 & 0.78 & 0.01 & 0.12 & 0.04 & 0.08 & 2.58 & 2.42 \\
\hline $\mathrm{Na}$ & 2.79 & 1.47 & 0.03 & 0.16 & 0.06 & 0.11 & 2.91 & 2.68 \\
\hline $\mathrm{Ca}$ & 3.523 & 3.4186 & 0.061 & 0.25 & 0.09 & 0.175 & 3.697 & 3.348 \\
\hline $\mathrm{Ba}$ & 0.445 & 0.8662 & 0.015 & 0.12 & 0.04 & 0.088 & 0.533 & 0.357 \\
\hline $\mathrm{Mg}$ & 0.240 & 0.0072 & 0.00013 & 0.01 & 0.004 & 0.008 & 0.248 & 0.232 \\
\hline $\mathrm{V}$ & 0.039 & 0.00004 & $7.6 \mathrm{E}-07$ & 0.001 & 0.0003 & 0.0006 & 0.040 & 0.039 \\
\hline $\mathrm{Zr}$ & 0.035 & 0.0011 & $1.9 \mathrm{E}-05$ & 0.004 & 0.0016 & 0.0031 & 0.038 & 0.031 \\
\hline $\mathrm{Cu}$ & 0.030 & 0.0009 & $1.54 \mathrm{E}-05$ & 0.004 & 0.0014 & 0.0028 & 0.033 & 0.027 \\
\hline $\mathrm{Pb}$ & 0.054 & 0.0017 & $2.98 \mathrm{E}-05$ & 0.005 & 0.0019 & 0.0039 & 0.058 & 0.050 \\
\hline$K$ & 0.059 & 0.0390 & 0.000697 & 0.026 & 0.0093 & 0.0187 & 0.077 & 0.040 \\
\hline $\mathrm{Zn}$ & 0.015 & 0.0001 & $1.5 \mathrm{E}-06$ & 0.001 & 0.0004 & 0.0009 & 0.016 & 0.015 \\
\hline $\mathrm{Ce}$ & 0.015 & $2.69375 E-05$ & $4.81 \mathrm{E}-07$ & 0.000694 & 0.0002 & 0.0005 & 0.016 & 0.015 \\
\hline La & 0.006 & $2.72609 \mathrm{E}-06$ & $4.87 \mathrm{E}-08$ & 0.000221 & $7.8 \mathrm{E}-05$ & 0.0002 & 0.0057 & 0.0054 \\
\hline $\mathrm{Sc}$ & 0.004 & $3.48484 \mathrm{E}-06$ & $6.22 \mathrm{E}-08$ & 0.0002 & 0.0001 & 0.0002 & 0.0038 & 0.0035 \\
\hline $\mathrm{Ga}$ & 0.002 & $2.72734 \mathrm{E}-06$ & $4.87 \mathrm{E}-08$ & 0.0002 & 0.0001 & 0.0002 & 0.0026 & 0.0023 \\
\hline $\mathrm{Y}$ & 0.003 & 0.00000066 & $1.18 \mathrm{E}-08$ & 0.000109 & $3.84 E-05$ & 0.0001 & 0.0031 & 0.0029 \\
\hline$A s_{\max }$ & 0.002 & 0 & 0 & 0 & 0 & 0 & 0.0020 & 0.0020 \\
\hline$S \mathrm{e}_{\max }$ & 0.002 & 0 & 0 & 0 & 0 & 0 & 0.0020 & 0.0020 \\
\hline$T h_{\max }$ & 0.002 & 0 & 0 & 0 & 0 & 0 & 0.0020 & 0.0020 \\
\hline $\mathrm{U}_{\max }$ & 0.002 & 0 & 0 & 0 & 0 & 0 & 0.0020 & 0.0020 \\
\hline $\mathrm{Hg}_{\max }$ & 0.001 & 0 & 0 & 0 & 0 & 0 & 0.0010 & 0.0010 \\
\hline $\mathrm{C}$ & 0.855 & 0.042 & 0.00075 & 0.0274 & 0.0097 & 0.0194 & 0.874 & 0.836 \\
\hline $\mathrm{H}_{2} \mathrm{O}$ & 32.054 & 50.74 & 0.906 & 0.952 & 0.337 & 0.673 & 32.73 & 31.38 \\
\hline $\mathrm{PC}\left(1000^{\circ} \mathrm{C}\right)$ & 39.985 & 26.06 & 0.465 & 0.682 & 0.241 & 0.482 & 40.47 & 39.50 \\
\hline
\end{tabular}




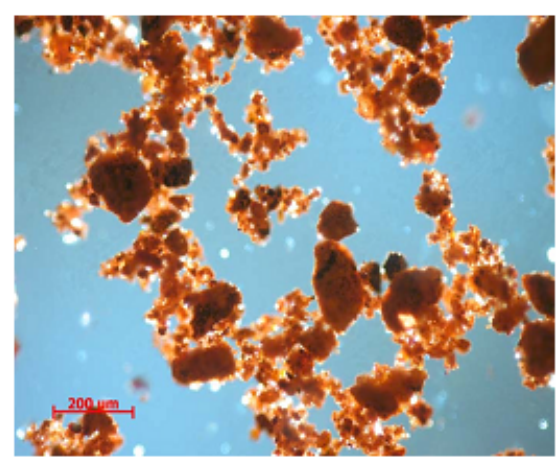

a)

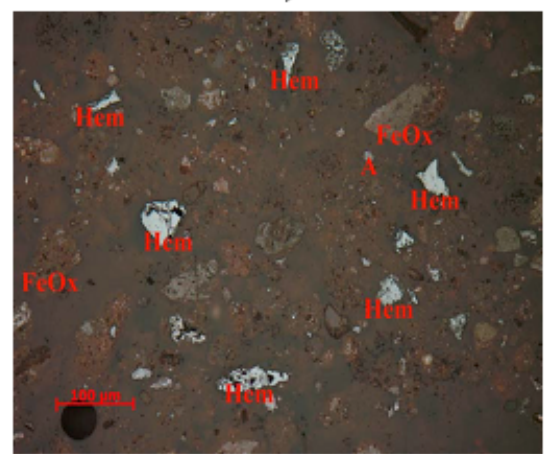

b)

Fig. 1. Red mud sample, IA, parallel nicoles, a) transmission light; b) reflected light (FeOx-iron oxides with earth aspects,

Hem-hematite, $\mathrm{A}$-anatase, $\mathrm{TiO}_{2}$ )

Table 3

SEMICANTITATIVE PHASE ANALYSIS, DRAYED RED MUD SAMPLE $\left(105^{\circ} \mathrm{C}, 2 \mathrm{H}\right)$

\begin{tabular}{|c|c|c|c|}
\hline Compound Name & Formula & S-Q $(\% \mathrm{~ms})$. & PDF Reference \\
\hline Hemafte & $\mathrm{Fe} 2 \mathrm{O3}$ & 30.4 & $01-087-1164\left(^{*}\right)$ \\
\hline Goethite & $\mathrm{FeO}(\mathrm{OH})$ & 9.7 & $01-081-0464$ (I) \\
\hline Diaspore & $\mathrm{AIO}(\mathrm{OH})$ & 7.6 & $01-084-0175\left(^{(*)}\right.$ \\
\hline Boehmite & $\mathrm{AlO}(\mathrm{OH})$ & 2.3 & $01-083-1505$ (I) \\
\hline Gobsite & $\mathrm{A}(\mathrm{OH}) 3$ & 10.6 & $01-074-1775(0)$ \\
\hline Calcte & $\mathrm{CaCO} 3$ & 9.2 & $01-071-3699\left(^{*}\right)$ \\
\hline Rutle & $\mathrm{TO} 2$ & 2.3 & $01-070-7347\left(^{*}\right)$ \\
\hline Cancrinite & $\mathrm{Na} 7.262(\mathrm{CO} 3) 0.932 \mathrm{~A} / 6 \mathrm{Si} 6 \mathrm{O} 24$ & 7.8 & $01-089-8592\left(^{*}\right)$ \\
\hline Cancrisilte & $\mathrm{Na} 7.86(\mathrm{~A} / 6 \mathrm{~S} / 6 \mathrm{O} 24)(\mathrm{CO} 3)(\mathrm{H} 2 \mathrm{O}) 3.3$ & 11.4 & $01-089-8047(\mathrm{~N})$ \\
\hline Hydrogamet & $\mathrm{Ca} 3 \mathrm{AlF} e(\mathrm{SIO} 4)(\mathrm{OH}) 8$ & 4.8 & $00-032-0147(\mathrm{C})$ \\
\hline Muscovite & $(\mathrm{K}, \mathrm{Na})(\mathrm{Al}, \mathrm{Mg}, \mathrm{Fe}) 2(\mathrm{Si} 3.1 \mathrm{Al} 0.9) \mathrm{O} 10(\mathrm{OH}) 2$ & 1.9 & $00-007-0042$ (I) \\
\hline Amesite & $(\mathrm{Ng} 2 \mathrm{~A})(\mathrm{AISIO}) \mathrm{S})(\mathrm{OH}) 4$ & 2.1 & $01-087-2057\left(^{(*)}\right.$ \\
\hline
\end{tabular}
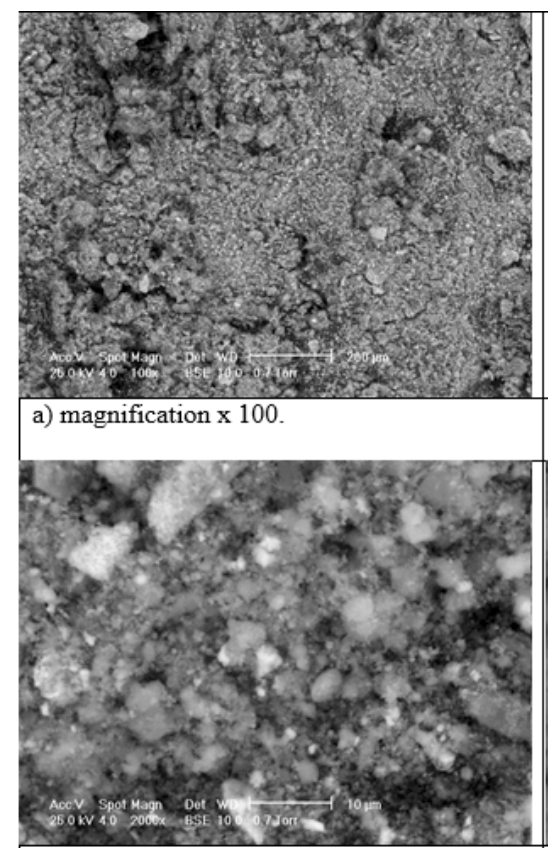

c) magnification $\times 2000$.

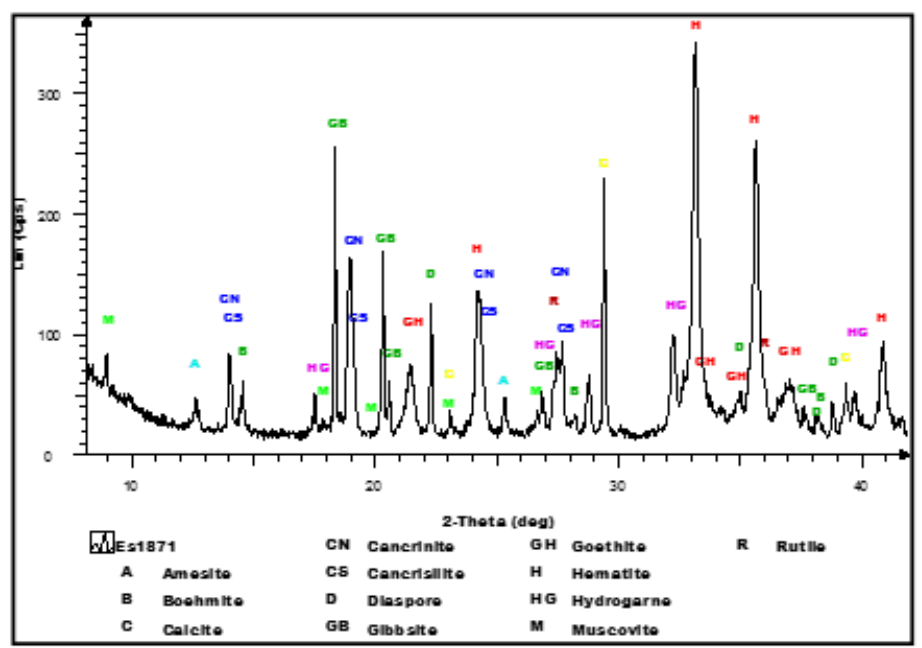

Fig. 2. Graphic presentation of X-ray analysis (XRD) for red mud sample drayed at $105^{\circ}$ for $2 \mathrm{~h}$, representative details of diagram
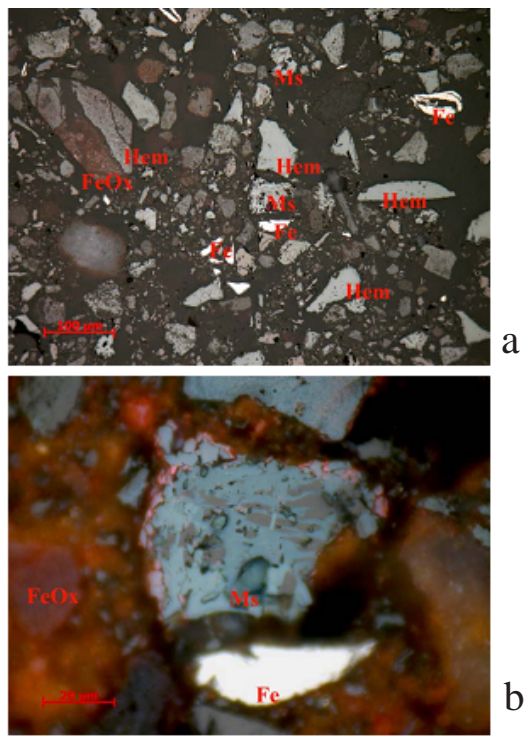

Fig. 3. Magnetic separation fraction (sample IA), nicoles parallel, a) reflected light; b) reflected light, immersion in cedru oil FeOx-iron oxides with earth aspect, Hemhematite, Ms-muschetovite, Fe- ferric metal.
Fig. 4. SEM Micrographs, showed shape and surface of red mud particles: irregular particles with variable size $(2-100 \mu \mathrm{m})$ b) magnification $\times 500$.

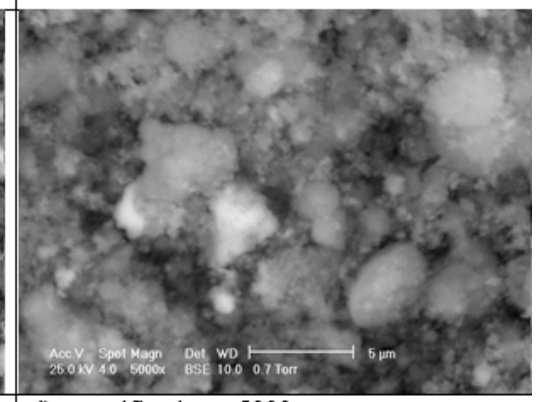

d) magnification $\times 5000$.

http://www.revistadechimie.ro 

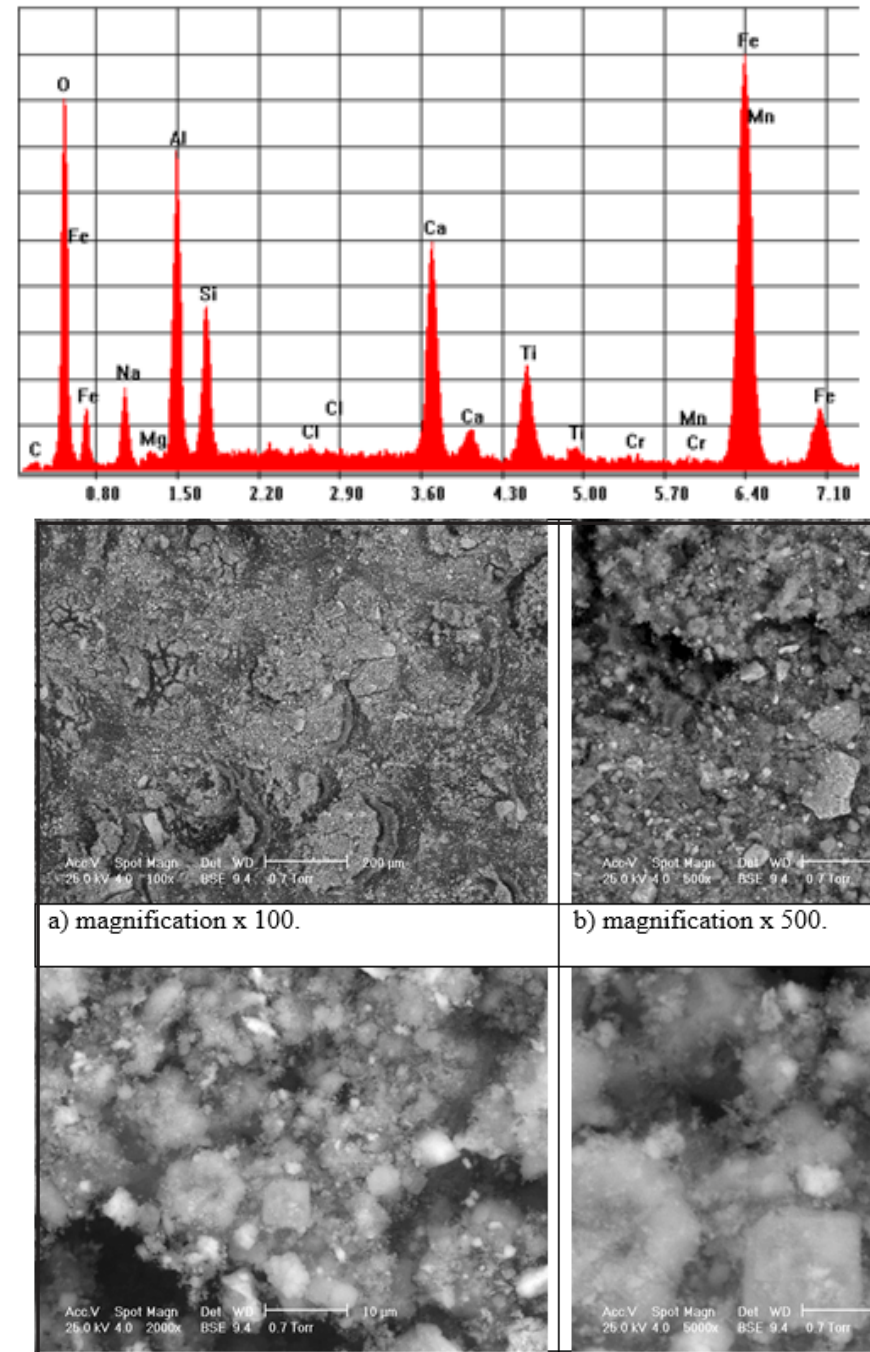

c) magnification $\mathrm{x} 2000$.

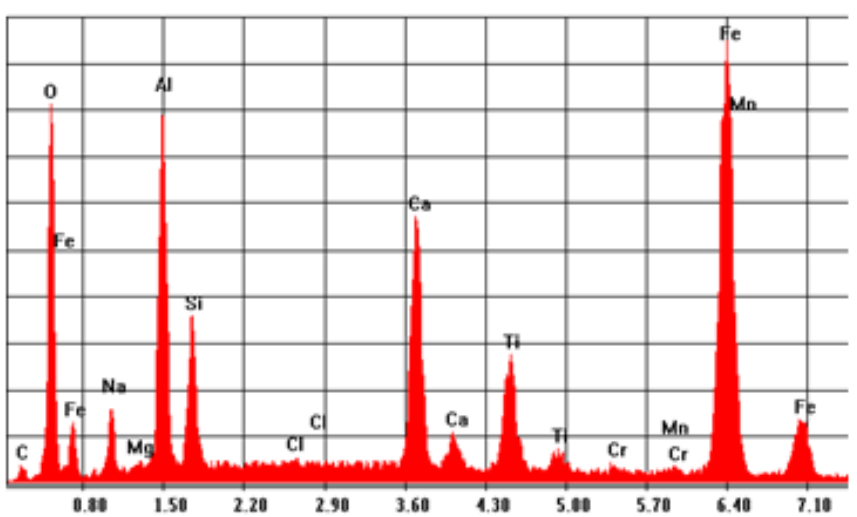

Fig. 7. Emission spectra of the X-ray radiations obtained in EDSEDAX analysis, washed red mud sample, IA probe, showed presence of $\mathrm{O}_{2}, \mathrm{Fe}, \mathrm{Na}, \mathrm{Al}, \mathrm{Ca}, \mathrm{Mg}, \mathrm{Si}, \mathrm{Ti}, \mathrm{Cr}, \mathrm{Mn}, \mathrm{Cl}$

to the change in the oxidation and reduction potential after the deposit of these materials from hydrothermal solutions.

We have also shown that the analysed red mud contains minor components and traces of $\mathrm{Ba}, \mathrm{Mg}, \mathrm{V}, \mathrm{Ti}, \mathrm{Zr}, \mathrm{Cu}, \mathrm{Pb}$, $\mathrm{Zn}, \mathrm{Ce}, \mathrm{La}, \mathrm{Sc}, \mathrm{Ga}$, Y, (table 1 and table 2). As far as the content of As, Se, Th, U, Hg is concerned, these elements have a concentration in the analyzed red mud under the detection limit of the devices used for chemical analysis.

The morphological and structural study results, obtained through imaging and quantitative composition corresponding to the $\mathrm{X}$-ray emission spectrum from EDSEDAX, SEM analysis, shown in figure $4(a, b, c, d)$ and figure 5 , respectively figure $6(a, b, c, d)$ and figure 7 , and through $\mathrm{XRF}$ analysis, conducted to investigate the distribution of
Fig. 5. Emission spectra of the X-ray radiations obtained in EDS-EDAX analysis, red mud sample, IA probe, showed presence of $\mathrm{O}_{2}, \mathrm{Fe}, \mathrm{Na}, \mathrm{Al}, \mathrm{Ca}, \mathrm{Mg}, \mathrm{Si}, \mathrm{Ti}, \mathrm{Cr}, \mathrm{Mn}, \mathrm{Cl}$
Fig. 6. SEM Micrographs, showed shape and surface of washed red mud particles: irregular particles with variable size $(2-100 \mu \mathrm{m})$

surface properties of the initial mud samples and those washed with distilled water, support the presented results obtained by chemical and structural analysis by X-ray diffraction and optical microscopy. The SEM images recorded at several resolutions of the samples of red mud present a non-uniform structure with agglomerations of crystallites in different areas and different dimensions, specific to the mixtures of oxides with a majority phase. After washing with distilled water the agglomerations of crystallites are preserved. It was also found thatby washing the mud samples at neutral $p \mathrm{H}$ ( $\mathrm{pH}$ 8-8.5), compounds like: $\mathrm{Gd}_{2} \mathrm{O}_{3^{\prime}} \mathrm{Ga}_{2} \mathrm{O}_{3}$, and $\mathrm{Sc}_{2} \mathrm{O}_{3^{\prime}}$ are not found any more in the washed mud sample.

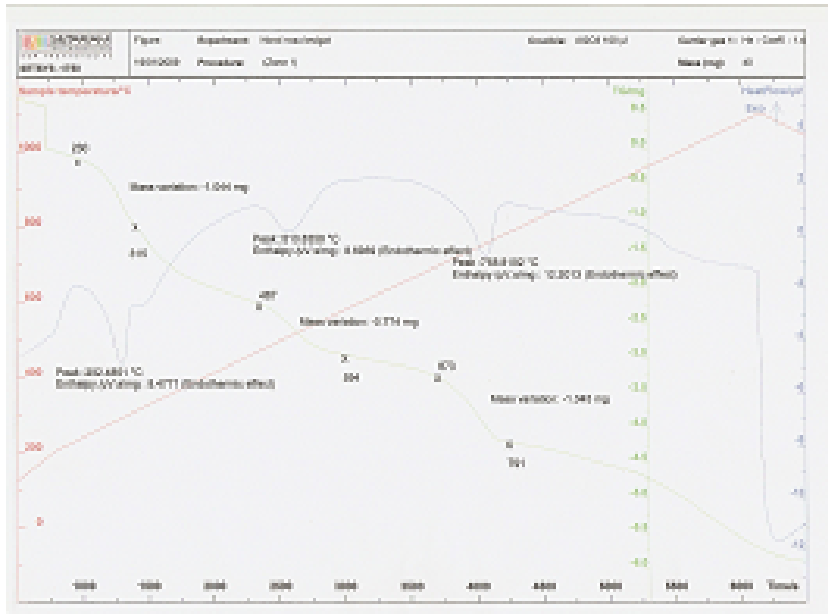

Fig. 8. Thermal DTAC curves of red sample, probe IA 


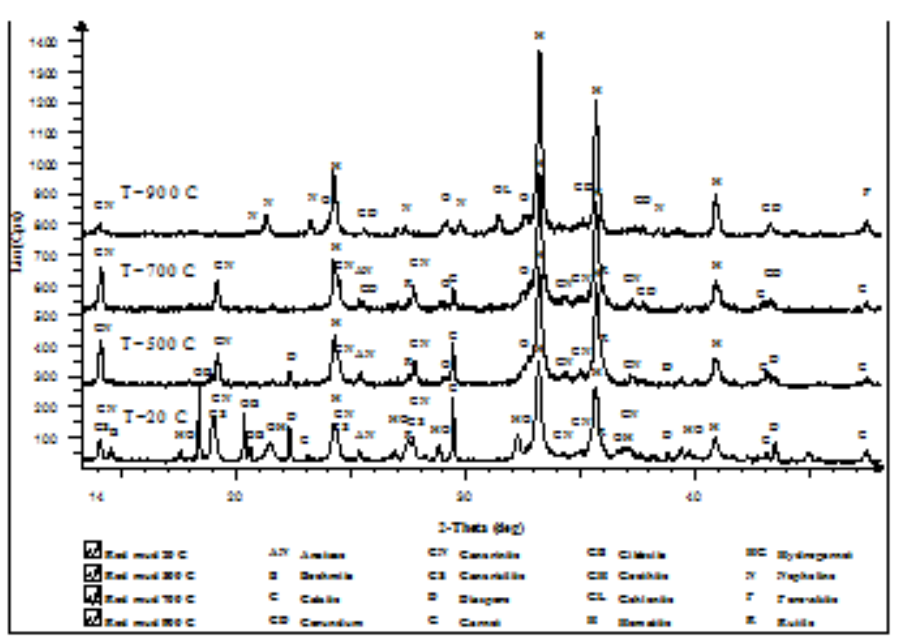

The thermal analysis (DTAC) indicates important mass losses in the domain $20-300^{\circ} \mathrm{C}$ (approximately $30 \%$ ) and losses on the order of $1.5-4 \%$ on the domains $300-500^{\circ} \mathrm{C}$, $500-700^{\circ} \mathrm{C}, 700-900^{\circ} \mathrm{C}$. The thermal differential analysis (DTAC) for the IA sample highlighted four peaks $\left(100^{\circ} \mathrm{C}\right.$, $292^{\circ} \mathrm{C}, 510^{\circ} \mathrm{C}, 768^{\circ} \mathrm{C}$ ) corresponding to endothermic effects due to losses of physically retained water and water included in aluminosilicates of zeolite type and also due to phase changes of aluminium and iron compounds: gibbsite transforms in up to corundum; goethite up to hematite, (figs. 8-9).

\section{Conclusions}

The physico-chemical, morphological and structural analysis of red mud samples revealed a complex composition, mostly formed by iron oxide with earth aspect (dispersed mainly in hematite) and goethite $\mathrm{FeO}(\mathrm{OH}$ ) and in small quantities in insoluble compounds of muscovite type or in compounds generated in the solubilisation of hidrogarnet type, aluminium oxides dispersed mainly in diaspore, boehmite, and gibbsite, but also in desiliciation compounds in the composition of cancrinite and cancrisilite (compounds of zeolite type) or in compounds generated in the solubilisation of hidrogarnet type, as well as insoluble compounds as muscovite and amesite. In small quantities on the order of percents, the following elements are found: $\mathrm{Si}, \mathrm{Na}, \mathrm{K}, \mathrm{Mg}$ and $\mathrm{Ca}$. In the magnetic separation, optical microscopy found metallic iron and muschetovite, magnetite pseudomorph phase, after hematite. Also, the analyzed red mud contains minor components and traces of $\mathrm{Ba}, \mathrm{Mg}, \mathrm{V}, \mathrm{Ti}, \mathrm{Zr}, \mathrm{Cu}, \mathrm{Pb}, \mathrm{Zn}, \mathrm{Ce}$, $\mathrm{La}, \mathrm{Sc}, \mathrm{Ga}, \mathrm{Y}$. As far as the As, Se, Th, U, Hg content is concerned, these elements have a concentration in the analyzed red mud under the detection limit of the devices used for chemical analysis. A high humidity level of the red mud was found, between $31-33 \%$ and calcinations losses $\left(1000^{\circ} \mathrm{C}\right)$ between $39-42 \%$.

\section{References}

1. ZHUROV,V.V., BOGATYREV, B.,DEMINA,L., MATVEYEVA,V., Int. Geo. Rev., 26, no.7, 1984, p.816;

2. BOGATYREV,B.A.,ZHUROV,V.V., TSEKHOVSKY,YU.G., Lit. Min. Res., 44, no.2, 2009, p.135;

3. ZHENG, K., GERSON, A.R.,ADDAI-MENSAH, J., SMART,R., J. Cryst. Growth, 171, no.1-2, 1997, p.197;

4. GERSON, A.R., ZHENG,K., J. Cryst. Growth, 171, no. 1-2, 1997, p.209;

5. BARNES,M.C., ADDAI-MENSAH, J., GERSON,A.R., Microporous and Mesoporous Materials, 31, no. 3, 1999, p.287;

6. BARNES, M.C., ADDAI-MENSAH, J.,GERSON, A.R., Colloid and Surfaces, A: Physicochemical and Engineering Aspects, 147, no.3, 1999,p.283;
Fig. 9. Red mud thermal transformations, showed in $X$-ray analysis (XRD) (representative details of diagrams)

7. BARNES,M.C.,ADDAI-MENSAH, J., GERSON,A.R., Microporous and Mesoporous Materials, 31, no.3, 1999, p. 303;

8. BARNES,M.C., ADDAI-MENSAH, J.,GERSON,A.R., Colloid and Surfaces, A: Physicochemical and Engineering Aspects, 157, no.1-3, 1999, p.101;

9. PASCUAL, J., CORPAS, F.A., LOPEZ-BECEIRO, J., BENITEZGUERRERO, M., ARTIAGA,R., J ournal of Thermal Analysis and Calorimetry, 96, no.2, 2009, p.407;

10. ATASOY, A., Journal of Thermal Analysis and Calorimetry, 90, no.1, 2007, p. 153;

11. NICULESCU, M., IONITA, A.D., FILIPESCU, L., Rev. Chim. (Bucharest), 60, no.11, 2009, p. 1189;

12. CASTALDI, P., SILVETTI, M., SANTONA, L., ENZO, S., MELIS, P., Clays and Clay Minerals, 56, no.4, 2008, p.461;

13. PALMER, S.J., REDDY, B.J ., FROST, R.L., Spectrochimica Acta Part A: Molecular and Biomolecular Spectroscopy, 71, no.5, 2009, p.1814; 14. WAGH, A.S., PINNOCK, W.R.,Economic Geology, 82, no.3, 1987, p. 757 ;

15. RESSWELL, P.J ., GRAYSON, J.L., SMITH, A.H., U.S.A. Pat., no. 4,668,485, Appl., no. 807,319;

16. SANTONA, L., CASTALDI, P., MELIS, P., J. Haz. Mat., 136, no. 2, 2006, p.32;

17. ZHANG, P.C., SPARKS, D.L., Environ. Sci. Technol., 24, no. 12, 1990, p. 1848;

18. SYLVESTER, P., WESTERHOFF, P., MOOLLER, T., BADRUZZAMAN, M., BOYD, O., Environ. Eng. Sci., 24, no. 1, p. 104;

19. LIU, W., YANG, J., XIAO, B., J. Haz. Mat., 161, no. 1, 2009, p.474; 20. YANG, J., ZHANG, D., HOU, J., HE, B., XIAO, B., Ceram. Int., 34, no. 1, 2008, p.125;

21. KHAITAN, S., DZOMBAK, D.A., LOWRY, G.V., Env. Eng. Sci., 26, no. 2, 2009, p. 431;

22. SGLAVO, V.M., MAURINA, S., CONCI, A., SALVIATI, A., CARTURAN, G., COCCO, G., J. Eur. Cer. Soc., 20, no. 3, 2000, p. 245;

23. KAVAS, T., Build. Env., 41, no. 12, 2006, p.1779;

24. BISWAS, S., SATAPATHY, A., Mat. Design, 30, no. 8, 2009, p. 2841; 25. JUSTIZ-SMITH, N., BUCHANAN, V.E., OLIVER, G., Mat. Sci. Eng.A., 420, no. 1-2, 2006, p.250;

26. SORUH, S., ERGUN, O.N., J. Haz. Mat., 173, no. 1-3, 2010, p. 468; 27. PALMER, S.J., FROST, R.L., NGUYEN, T., Coord. Chem. Rev., 253, no. 1-2, 2009, p.250;

28. PEAK, D., SPARKS, D.L., Environ. Sci. Technol., 36, no. 7, 2002, p. 1460 ;

29. APPELO, C.A.J., VAN DER WEIDEN, M.J.J., TOURNASSAT, C., CHARLET, L., Environ. Sci. Technol., 36, no. 14, 2002, p. 3096;

30. ION, C.S., BOMBOS, M., VASILIEVICI, G., PANAITESCU, C., DRAGOMIR, R., Rev. Chim. (Bucharest), 68, no. 4, 2017, p.732;

31. NICULESCU, M., IONITA, A.D., FILIPESCU, L., Rev. Chim. (Bucharest), 60, no. 11, 2009, p. 1189.

Manuscript received: 7.03 .2018 